\title{
Estudo comparativo de três diferentes procedimentos para extração de RNA a partir de amostras fixadas em formalina e embebidas em parafina
}

\author{
Comparative study of three different procedures for RNA extraction from formalin-fixed \\ paraffin-embedded samples
}

Alfredo Ribeiro-Silva'; Sérgio Britto Garcia²

\begin{tabular}{|c|c|}
\hline & \\
\hline $\begin{array}{l}\text { RNA } \\
\text { Formalina } \\
\text { Parafina } \\
\text { Protocolo } \\
\text { Biologia molecular }\end{array}$ & 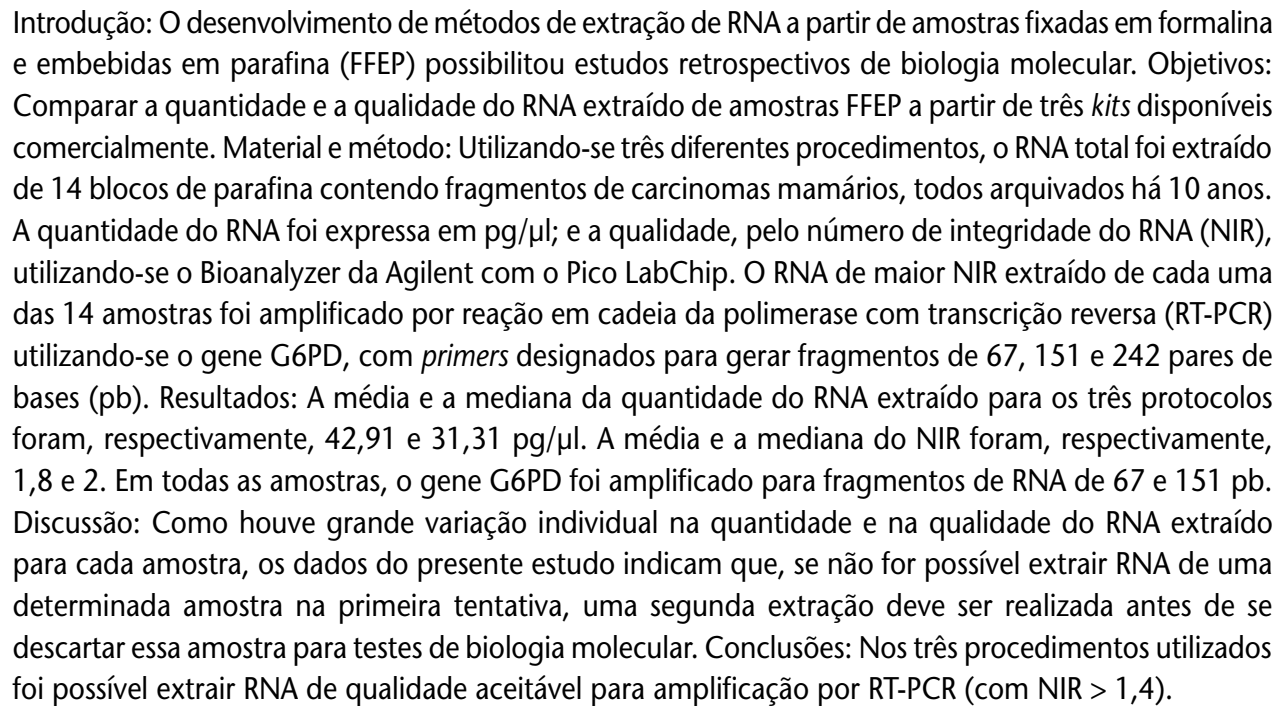 \\
\hline
\end{tabular}

abstract

Background: The development of methods for RNA extraction from formalin-fixed paraffin-embedded (FFPE) samples has allowed retrospective studies of molecular biology. Objectives: To compare the quantity and quality of RNA extracted from FFPE samples using three commercially available kits. Material and methods: Using three different procedures, the total RNA was extracted from 14 paraffin blocks containing fragments of mammary carcinomas, which had been archived for 10 years. The quantity of RNA was expressed in pg/ $\mu$ l; and the quality in RNA integrity number (RIN), by using the Agilent Bioanalyser with Pico LabChip. The RNA with higher RIN extracted from each of the 14 samples was amplified by reverse transcriptase-polymerase chain reaction (RT-PCR) using the G6PD gene with primers designed to create fragments with 67, 151 and 242 base pairs (bp). Results: The mean and median of RNA quantity extracted for the three procedures were respectively 42.91 and $31.31 \mathrm{pg} / \mu \mathrm{l}$. The mean and median of RIN were respectively 1.8 and 2. In all the samples, the G6PD gene was amplified for RNA fragments with 67 and $151 \mathrm{bp}$. Discussion: Due to the significant individual variation in quantity and quality of the extracted RNA from each sample, the data from the present study show that, if it is not possible to extract RNA from a given sample in the first attempt, a second extraction should be performed before excluding this sample. Conclusion: It was possible to extract $R N A$ with acceptable quality for amplification by RT-PCR $(R I N>1.4)$ in the three procedures used.

\section{key words}

RNA

Formalin

Paraffin

Protocol

Molecular biology

1. Professor-doutor do Departamento de Patologia da Faculdade de Medicina de Ribeirão Preto da Universidade de São Paulo (FMRP/USP).

2. Professor associado do Departamento de Patologia da FMRP/USP.

Este trabalho contou com o apoio financeiro da Coordenação de Aperfeiçoamento de Pessoal de Nível Superior (CAPES), processo BEX0762067. 


\section{Introdução}

As amostras de tecido humano obtidas de procedimentos cirúrgicos são rotineiramente fixadas em formalina e embebidas em parafina (FFEP) para arquivamento em longo prazo. Por isso, a maioria das instituições possui grandes arquivos de blocos de parafina. Esses arquivos representam importante fonte de material para estudos retrospectivos. A fixação em formalina e o conseqüente processamento histológico provocam, em grau variável, degradação e modificação química do RNA, o que pode prejudicar o uso dessas amostras para estudos de expressão gênica. Sabe-se que o congelamento de tecido a fresco, coletado durante $o$ ato cirúrgico, preserva o RNA, permitindo que seja utilizado para estudos de biologia molecular. Entretanto, esse procedimento não é rotineiro na maioria dos hospitais brasileiros e poucas instituições dispõem de bancos de tecido congelado. Por este motivo, a extração de RNA com qualidade que torne viável os estudos de biologia molecular a partir de tecido FFEP é um desafio constante para o patologista.

A primeira extração bem-sucedida de RNA a partir de material FFEP foi descrita por Rupp e Locker, em 1988 $8^{(14)}$. Numerosos protocolos têm sido descritos desde então $0^{(1,5,}$ $6,8,9,11)$. Como não existe um consenso acerca do melhor procedimento a ser adotado na prática, e como as técnicas de biologia molecular dependem da quantidade e da qualidade do RNA extraído, esse trabalho teve por objetivo avaliar três diferentes procedimentos de extração de RNA a partir de material FFEP.

\section{Objetivo}

Utilizando três kits de extração de RNA, o presente estudo teve por objetivo comparar a quantidade e a qualidade do RNA extraído de amostras de carcinomas mamários humanos incluídos em blocos de parafina arquivados há 10 anos.

\section{Material e método}

\section{Amostras}

Este trabalho segue os princípios éticos da Resolução no 196/96 do Conselho Nacional de Saúde e foi aprovado pelo comitê de ética local. Os blocos foram obtidos no arquivo do Serviço de Patologia do Hospital das Clínicas da Faculdade de Medicina de Ribeirão Preto da Universidade de São Paulo
(HCFMRP/USP). Foram selecionados ao acaso 14 blocos de parafina contendo amostras de carcinomas mamários com pelo menos 1,5 por $1,5 \mathrm{~cm}$ em área, diagnosticados em 1997 (10 anos de arquivamento). Utilizando-se um micrótomo convencional (Leica RM2125), a partir de cada bloco foram obtidos cortes histológicos de espessura variável, conforme o protocolo empregado (Tabela 1). Para cada bloco foi usada uma navalha nova, a fim de que não houvesse contaminação entre as amostras. Antes de cada reação, as bancadas e os instrumentos foram borrifados com a solução RNaseZap (Ambion Inc., Austin, TX, EUA). Todos os procedimentos foram feitos com luvas descartáveis e todas as ponteiras e microtubos eram livres de degradação do RNA por ribonucleases (RNAse).

\section{Extração de RNA}

Todos os procedimentos foram realizados conforme instrução dos fabricantes. O protocolo 1 utiliza o kit RecoverAll Total Nucleic Acid Isolation Optimized for FFPE Samples (Ambion Inc., Austin, TX, EUA) (www.ambion.com/techlib/ prot/fm_1975.pdf); o protocolo 2 usa o kit High Pure RNA Paraffin Kit (Roche Applied Science, Mannheim, Alemanha) (www.roche-applied-science.com/pack-insert/3270289a. pdf); e o protocolo 3, o Absolutely RNA FFPE Kit (Stratagene, La Jolla, CA, EUA) (www.stratagene.com/manuals/400809. pdf).

Cada um desses procedimentos consiste, basicamente, em seis etapas: obtenção dos cortes histológicos, desparafinização, digestão com proteinase $\mathrm{K}$ (para remover as ligações cruzadas do RNA com proteínas), isolamento do RNA, incubação com DNAse e purificação do $\operatorname{RNA}^{(9,12)}$. A Tabela 1 ressalta as principais diferenças entre os três procedimentos utilizados nesse trabalho.

\section{Avaliação de quantidade e qualidade do RNA extraído}

A quantidade e a qualidade do RNA extraído foram avaliadas utilizando-se o equipamento Agilent 2100 Bioanalyser com o Pico LabChip Kit (Agilent Technologies, Palo Alto, $\mathrm{CA})$, conforme instruções do fabricante. A quantidade foi expressa em $\mathrm{pg} / \mu \mathrm{l}$ e a qualidade, pelo número de integridade do RNA (NIR).

\section{Análise estatística}

A análise estatística para comparação dos resultados obtidos com os diferentes procedimentos foi realizada utilizando o software GraphPad Prism 4.0 (San Diego, CA). 


\section{Tabela 1 Principais diferenças entre os três kits utilizados}

\begin{tabular}{|c|c|c|c|}
\hline Parâmetro & Kit 1 & Kit 2 & Kit 3 \\
\hline Cortes histológicos & 4 de $20 \mu \mathrm{m}(80 \mu \mathrm{m})$ & 1 de $10 \mu \mathrm{m}(10 \mu \mathrm{m})$ & 2 de $10 \mu \mathrm{m}(20 \mu \mathrm{m})$ \\
\hline Desparafinização & $\begin{array}{c}1 \mathrm{ml} \text { de xilol a } 100 \% \\
\left(3 \text { min a } 55^{\circ} \mathrm{C}\right)\end{array}$ & $\begin{array}{c}800 \mu \mathrm{l} \text { d-limonene } \\
(5 \text { min em TA) }\end{array}$ & $\begin{array}{l}1 \mathrm{ml} \mathrm{d} \text {-limonene } \\
\text { (10 min em TA) }\end{array}$ \\
\hline Incubação com proteinase $\mathrm{K}$ & 3 horas a $50^{\circ} \mathrm{C}$ & Overnight a $55^{\circ} \mathrm{C}$ & 3 horas a $55^{\circ} \mathrm{C}$ \\
\hline Isolamento dos RNAs & $\begin{array}{l}\text { Solução de isolamento } \\
\text { fornecida pelo kit } 1\end{array}$ & $\begin{array}{l}\text { Solução de isolamento } \\
\text { fornecida pelo kit } 2\end{array}$ & $\begin{array}{l}0,875 \mu \mathrm{l} \text { de mercaptoetanol } \\
\text { em } 125 \mu \mathrm{l} \text { de tampão } \\
\text { fornecido pelo kit } 3\end{array}$ \\
\hline Incubação com DNase & 30 min a $37^{\circ} \mathrm{C}$ & 45 min a $37^{\circ} \mathrm{C}$ & $15 \min$ a $37^{\circ} \mathrm{C}$ \\
\hline Purificação do RNA & $\begin{array}{l}\text { Soluções fornecidas pelo } \\
\text { kit } 1\end{array}$ & $\begin{array}{l}\text { Soluções fornecidas pelo } \\
\text { kit } 2\end{array}$ & $\begin{array}{l}\text { Soluções fornecidas pelo } \\
\text { kit } 3\end{array}$ \\
\hline
\end{tabular}

TA: temperatura ambiente; kit 1: RecoverAll Total Nucleic Acid Isolation Optimized for FFPE Samples; kit 2: High Pure RNA Paraffin Kit; kit 3: Absolutely RNA FFPE Kit.

Tanto para a quantidade $(\mathrm{pg} / \mu \mathrm{l})$ como para a qualidade (NIR) do RNA extraído foi feita uma análise descritiva com os seguintes parâmetros: valor mínimo, valor máximo, média, mediana e desvio padrão. Utilizou-se o teste não-paramétrico de Mann-Whitney para comparação dos resultados, sendo previamente estabelecido que $\alpha=0,05$.

\section{Reação em cadeia da polimerase com transcrição reversa (RT-PCR)}

A técnica de RT-PCR foi realizada no RNA de maior NIR obtido de cada uma das 14 amostras. O gene glicose-6fosfato desidrogenase (G6PD) foi utilizado para determinar o tamanho dos fragmentos de RNA, conforme descrito por Liu et al.(10). Um primer sense (5'-GGC AAC AGA TAC AAG AAC GTG AA) e três primers antisense foram utilizados de modo a gerar produtos de amplificação de 67 pares de bases (5'-CGC AGA AGA CGT CCA GGA T), 151 pares de bases (5'-CCA GCT CAA TCT GGT GCA G) e 242 pares de bases (5'-CCC TCA TAC TGG AAA CCC ACT).

A reação do RT-PCR multiplex foi feita utilizando-se o kit Superscript ${ }^{\mathrm{TM}}$ III One-Step RT-PCR with Platinum Tag system (Invitrogen ${ }^{\circledast}$, Carlsbad, CA), conforme orientação do fabricante. As reações foram otimizadas com RNA humano universal de referência (Stratagene ${ }^{\circledR}$, La Jolla, CA). Para cada amostra foram utilizados 100 pg do RNA extraído. Para cada amostra foram utilizados $250 \mathrm{pmol}$ do primer sense e 100 pmol do primer antisense. A amplificação foi feita no termociclador MyCycler (Bio-Rad ${ }^{\circledR}$, Hercules, CA). A primeira etapa da transcrição foi feita a $50^{\circ} \mathrm{C}$ por 30 minutos, seguida de aquecimento a $94^{\circ} \mathrm{C}$ por 2 minutos, um ciclo de desnaturação a $94^{\circ} \mathrm{C}$ por 30 segundos, anelamento a $66^{\circ} \mathrm{C}$ por 30 segundos, extensão a $68^{\circ} \mathrm{C}$ por 45 segundos e, então, 30 ciclos de $94^{\circ} \mathrm{C}$ por 30 segundos, $58^{\circ} \mathrm{C}$ por 30 segundos e $68^{\circ} \mathrm{C}$ por 45 segundos. A extensão final foi feita a $68^{\circ} \mathrm{C}$ por 10 minutos. As reações foram analisadas por eletroforese em gel de agarose a $2 \%$ e visualizadas pelo corante brometo de etídio.

\section{Resultados}

A Tabela 2 mostra, para cada um dos 14 casos analisados, a quantidade e a qualidade do RNA extraído com cada um dos três procedimentos. A quantidade está expressa em $\mathrm{pg} / \mu \mathrm{l}$ e a qualidade, pelo NIR. De acordo com a Tabela 2, utilizando os procedimentos 1,2 e 3, foi possível obter RNA com qualidade mínima para amplificação em PCR (NIR > $1,4)$ em novo $(64,3 \%), 10(71,4 \%)$ e $12(85,7 \%)$ das 14 amostras examinadas, respectivamente.

A Tabela 3 mostra os valores mínimos e máximos, as médias, as medianas e os desvios padrão para cada um dos procedimentos em relação à quantidade e à qualidade do RNA extraído (NIR).

Comparando-se a qualidade do RNA extraído, verifica-se que os procedimentos 1, 2 e 3 apresentaram NIR médio de 1,$4 ; 1,9$ e 2,1 , respectivamente. Essas diferenças não foram estatisticamente significantes $(p=0,9751)$ quando analisadas pelo teste de Mann-Whitney. Na mediana os valores foram iguais para os procedimentos 2 e 3 (NIR de 2,2) (Tabela 3), não havendo também diferença estatisticamente significativa entre os procedimentos $(p=0,0936)$.

A Tabela 2 mostra a existência de discrepância no sucesso de extração de RNA entre amostras individuais. Por exemplo, das amostras 1, 4, 6 e 7 não foi possível extrair RNA apenas com o procedimento 1, mas utilizando-se 
Comparação entre os três procedimentos conforme a quantidade do RNA extraído (expresso em

Tabela 2 pg/pl) e o NIR para cada uma das amostras examinadas

\begin{tabular}{|c|c|c|c|c|}
\hline Amostra & Parâmetro & Procedimento 1 & Procedimento 2 & Procedimento 3 \\
\hline \multirow[t]{2}{*}{1} & RNA & 91,464 & 32,507 & 21,078 \\
\hline & NIR & NA & 3,5 & 2,2 \\
\hline \multirow[t]{2}{*}{2} & RNA & 27,124 & 165,588 & 38,415 \\
\hline & NIR & 1,7 & 2,1 & 2,2 \\
\hline \multirow[t]{2}{*}{3} & RNA & 1,236 & 11,05 & 1,416 \\
\hline & NIR & 2,3 & 2,3 & 2,4 \\
\hline \multirow[t]{2}{*}{4} & RNA & 5,103 & 71,598 & 34,381 \\
\hline & NIR & NA & 2,2 & 2,3 \\
\hline \multirow[t]{2}{*}{5} & RNA & 5,146 & 43,901 & 29,711 \\
\hline & NIR & 1,7 & NA & NA \\
\hline \multirow[t]{2}{*}{6} & RNA & 11,416 & 99,045 & 18,686 \\
\hline & NIR & NA & 2,2 & 2,4 \\
\hline \multirow[t]{2}{*}{7} & RNA & 160,254 & 98,598 & 16,501 \\
\hline & NIR & NA & 2,2 & 1,2 \\
\hline \multirow[t]{2}{*}{8} & RNA & 65,752 & 66,706 & 46,519 \\
\hline & NIR & 1,2 & 3,2 & 2,4 \\
\hline \multirow[t]{2}{*}{9} & RNA & 15,123 & 32,962 & 137,594 \\
\hline & NIR & 1,5 & 5,2 & 2,2 \\
\hline \multirow[t]{2}{*}{10} & RNA & 31,042 & 68,465 & 35,551 \\
\hline & NIR & 2,2 & NA & 3,6 \\
\hline \multirow[t]{2}{*}{11} & RNA & 19,588 & 30,333 & 34,319 \\
\hline & NIR & 2,2 & NA & 2,5 \\
\hline \multirow[t]{2}{*}{12} & RNA & 5,883 & 29,701 & 67,125 \\
\hline & NIR & 2 & 1,5 & 2,3 \\
\hline \multirow[t]{2}{*}{13} & RNA & 30,578 & 45,229 & 21,065 \\
\hline & NIR & 2,2 & NA & 2,2 \\
\hline \multirow[t]{2}{*}{14} & RNA & 3,099 & 22,218 & 9,518 \\
\hline & NIR & 2,3 & 2,4 & 2,2 \\
\hline
\end{tabular}

NIR: número de integridade do RNA; NA: não-adequado.

Tabela 3 pg/pl) e ao NIR

Comparação entre os três procedimentos conforme os valores mínimos e máximos, médias, medianas e desvios padrões verificados em relação à quantidade do RNA extraído (expressa em

\begin{tabular}{ccccc}
\hline \multirow{2}{*}{ RNA $(p g / \mu l)$} & Procedimento 1 & Procedimento 2 & Procedimento 3 \\
& Valor mínimo & 1,236 & 11,05 & 1,416 \\
& Valor máximo & 160,3 & 165,6 & 137,6 \\
& Média & 33,77 & 58,42 & 36,56 \\
\multirow{2}{*}{ NIR } & Mediana & 17,36 & 44,57 & 32,02 \\
& Desvio padrão & 44,62 & 41,11 & 33,36 \\
& Valor mínimo & 0 & 0 & 0 \\
& Valor máximo & 2,3 & 5,2 & 3,6 \\
& Média & 1,4 & 1,9 & 2,1 \\
& Mediana & 1,7 & 2,2 & 2,2 \\
& Desvio padrão & 0,9 & 1,5 & 0,7 \\
\hline
\end{tabular}


os outros dois procedimentos foi possível essa extração com qualidade satisfatória (NIR > 1,4). Com o uso do procedimento 2 não foi possível extrair RNA de qualidade satisfatória (NIR > 1,4) das amostras 10, 11 e 13. Entretanto, nesses mesmos casos, foi possível a extração com qualidade satisfatória com os protocolos 1 e 3 . A amostra 5 foi a única da qual não foi possível extrair RNA com dois dos procedimentos utilizados (2 e 3). Entretanto, nesse mesmo caso, foi possível extrair RNA satisfatório $(N I R=1,7)$ com o procedimento 1 .

A Figura 1 mostra três exemplos de curvas de eletroesferograma. A Figura $1 \mathrm{~A}$ corresponde à amostra 3 , avaliada pelo procedimento 3 ; a Figura $1 \mathrm{~B}$, à amostra $1 \mathrm{com} 0$ procedimento 2; e a Figura $1 \mathrm{C}$ corresponde à amostra 11 com o procedimento 3 .

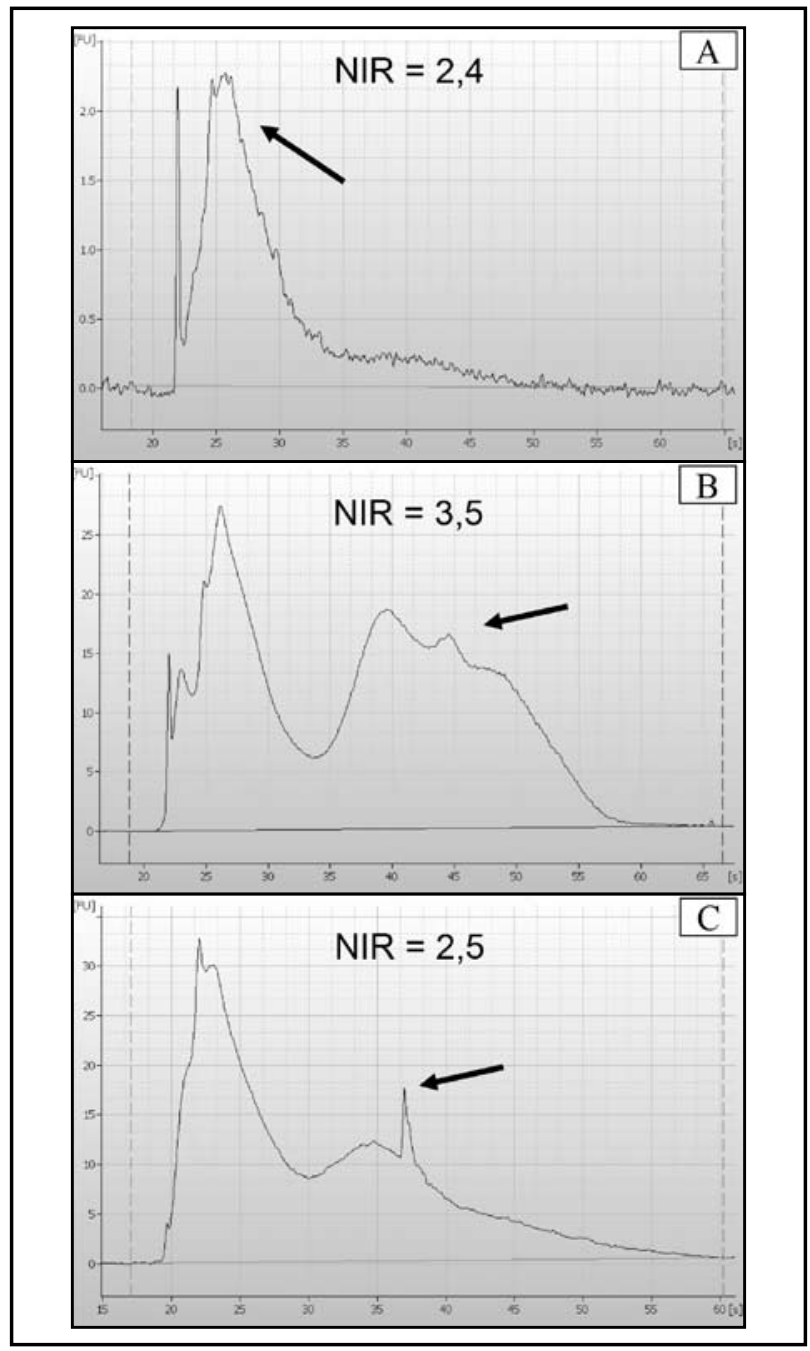

Figura 1 - Três exemplos de curvas de eletroesferograma. 1A: observa-se um único pico agudo (seta), indicando fragmentos de RNA de pequeno tamanho. Esse foi o padrão mais comum; 1B: observam-se dois picos, sendo que o segundo tende a formar um platô (seta). Esse tipo de curva indica fragmentos de RNA de diferentes tamanhos. Os picos 185 e 28S, típicos do RNA extraído de material a fresco e congelado, não foram vistos nas amostras examinadas; 1C: mostra um pico em $18 \mathrm{~S}$ (seta) NIR: número de integridade do RNA.
Nas 14 amostras o gene G6PD foi amplificado por RTPCR para fragmentos de RNA de 67 e 151 pares de bases. Em nenhuma das amostras, entretanto, houve amplificação em fragmentos de RNA de 242 pb (Figura 2).

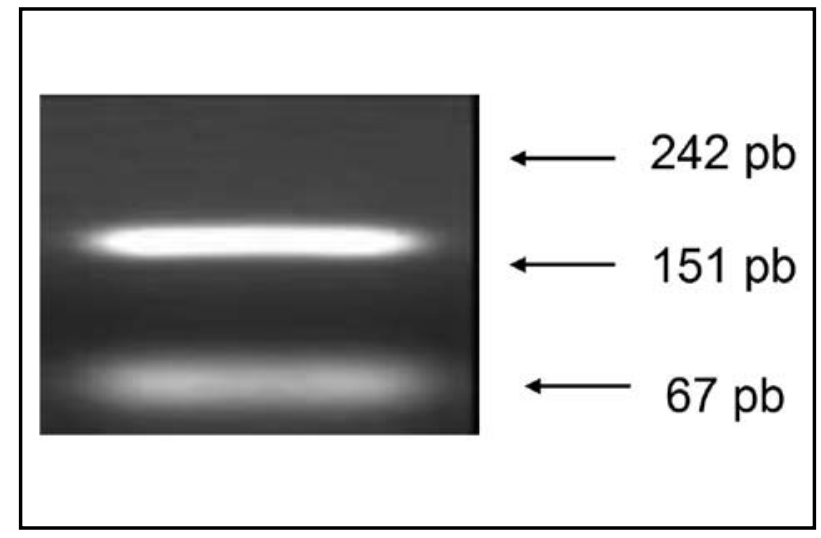

Figura 2 - Exemplo de amplificação do gene G6PD por RT-PCR do tipo multiplex. Observase banda de amplificação correspondente aos primers de 67 e 151 pares de bases. Não houve amplificação para o primer de 242 pb (amostra 10, procedimento 3, NIR =3,6)

\section{Discussão}

As biópsias e as peças cirúrgicas são rotineiramente fixadas em formalina para posterior processamento histológico. Embora preservem a integridade morfológica dos tecidos para análise histológica, esses procedimentos dificultam a obtenção de ácidos nucléicos, sobretudo RNA, para estudos de biologia molecular. O desenvolvimento de procedimentos de extração de RNA a partir de amostras FFEP possibilitou estudos de biologia molecular em material arquivado, abrindo novas perspectivas não apenas para pesquisa, mas também para a investigação diagnóstica.

Logo após a retirada do espécime cirúrgico, o RNA começa a se degradar pela ação de RNAses presentes no meio ambiente ${ }^{(3)}$. Entretanto, o maior desafio é que, além da degradação, o RNA é quimicamente modificado pela formalina. A formalina cria ligações cruzadas do RNA com proteínas, além de acrescentar um grupo monometilol aos grupos amino de quatro bases do RNA. Felizmente, ao menos parte dessas alterações pode ser desfeita pelo calor $^{(12)}$. Ademais, numerosas tentativas têm sido feitas para se evitar a ocorrência dessas modificações, sobretudo no que diz respeito ao fixador empregado. Por exemplo, fixadores como Bouin, Carnoy, acetona ou álcool têm sido propostos como substitutos para a formalina ${ }^{(2)}$. Eles, entretanto, introduzem artefatos no tecido que dificultam a análise histopatológica, além de muitas vezes inviabili- 
zarem reações de imuno-histoquímica, as quais são muito mais freqüentemente utilizadas na prática diagnóstica do que a extração dos ácidos nucléicos. Por esse motivo, ao invés de se tentar modificar o método de fixação tradicional, é mais lógico desenvolver e aprimorar protocolos de extração de RNA a partir de material fixado em formalina. Na maioria dos kits disponíveis comercialmente, o RNA é extraído em uma coluna de purificação, seguindo-se seis princípios básicos:

- obtenção de cortes histológicos: para evitar contaminação entre as amostras, uma navalha nova ou esterilizada deve ser usada para cada bloco de parafina;

- desparafinização: o primeiro desafio na extração do RNA é a desparafinização completa do tecido. Se for incompleta, o RNA extraído será de pior qualidade ${ }^{(2)}$. A desparafinização pode ser feita com xilol ou com a substância $d$-limonene (Stratagene, La Jolla, CA) (2);

- uso da proteinase K: a proteinase K é capaz de degradar as proteínas que estão fazendo ligações cruzadas com os ácidos nucléicos. $\mathrm{A}$ incubação com proteinase $\mathrm{K}$ aquecida a $60-70^{\circ} \mathrm{C}$ também remove, dos pares de bases, parte dos grupos metilol adicionados pela fixação em formalina;

- isolamento do RNA: após a incubação com a proteinase K, o RNA é isolado por agentes caotrópicos, que são potentes proteínas desnaturantes que previnem a RNAse. $\mathrm{O}$ agente caotrópico mais usado é o sal guanidina tiocinato;

- incubação com DNAse: para remover o DNA presente na amostra;

- purificação do RNA: a eliminação de resíduos e contaminantes é feita pela precipitação em álcool em coluna porosa.

Historicamente, a integridade do RNA tem sido avaliada por meio de gel de agarose corado pelo brometo de etídio. Tipicamente, esses géis mostram duas bandas correspondentes ao RNA ribossomal: $28 \mathrm{~S}$ e $18 \mathrm{~S}$. Por essa técnica, um RNA é considerado de boa qualidade quando a relação 28S:18S é igual ou maior a 2. Essa interpretação, entretanto, é subjetiva e pouco reprodutível(13). Em 1999, A empresa Agilent introduziu o sistema 2100 bioanalyzer para separação de DNA, RNA e proteínas das amostras. Por essa técnica, pequenas quantidades de RNA são separadas de acordo com seu peso molecular em canais presentes em um chip para, só então, serem analisados por fluorescência. O resultado é dado sob a forma de uma curva de eletroesferograma ${ }^{(13)}$. A partir dessas curvas, um total de 1.208 amostras de RNA provenientes de várias fontes $\mathrm{e}$ em diferentes graus de degradação foram analisados e um algoritmo foi criado. Esse algoritmo, denominado NIR, vai de 1 a 10, sendo que o 1 representa a pior qualidade e o 10 , a melhor ${ }^{(15)}$.

Em material congelado consegue-se obter um NIR de 8,5 a 9,5. Entretanto, em material fixado em formalina, esse valor é muito inferior porque o RNA encontra-se degradado em pequenos fragmentos. Não obstante, fragmentos de apenas 60 pares de bases são suficientes para se obter uma amplificação bem-sucedida em $80 \%$ das reações de $\mathrm{PCR}$, mesmo com RNA extraído de material arquivado por longo período(7). Além disso, a empresa Affymetrix desenvolveu chips de microarranjos (microarrays) denominados $\mathrm{X} 3 \mathrm{P}$, próprios para tecidos parafinizados, que requerem apenas 300 pares de bases ${ }^{(11)}$. Dessa maneira, com o RNA extraído de material parafinado é possível se realizar a maioria das técnicas de biologia molecular, incluindo Northern Blot, PCR, hibridização in situ e microarranjos de DNA complementar.

De acordo com Madabusi et al., um NIR de 1,4 é suficiente para a maioria dos testes moleculares, incluindo microarranjos de DNA complementar ${ }^{(11)}$. Por esse motivo, no presente trabalho esse valor de 1,4 foi adotado como limite inferior de NIR para se considerar o RNA como de qualidade aceitável para testes de biologia molecular.

Como houve muita variação individual na quantidade e na qualidade do RNA extraído pelo emprego de cada um dos três procedimentos, os resultados do presente estudo indicam que, se não for possível extrair RNA com NIR $>1,4$ de uma determinada amostra, uma segunda extração deve ser realizada com o mesmo procedimento antes de descartá-la para testes de biologia molecular. Além disso, os nossos dados corroboram a observação feita por Chung et al. de que quantidade e qualidade são fatores independentes na extração do RNA ${ }^{(2)}$. Por exemplo, na amostra 7, com o procedimento 1, foi possível extrair $160,254 \mathrm{pg} / \mu \mathrm{l}$ de RNA, mas de qualidade inadequada. Por outro lado, na amostra 3, com o procedimento 1, foi possível extrair apenas $1,236 \mathrm{pg} / \mathrm{\mu l}$ de RNA, mas com um NIR de 2,3, que está acima da média obtida com o uso dos três procedimentos.

A média dos NIRs obtida com os três procedimentos utilizados no presente estudo foi de 1,8. Esse mesmo resultado foi verificado por Chung et al. ${ }^{(2)}$, que verificaram um NIR de 1,8 para amostras de mama parafinizadas há 
apenas 60 dias, ressaltando-se que, no presente trabalho, os blocos estavam arquivados há 10 anos.

Em relação à quantidade, os procedimentos 1, 2 e 3 possibilitaram a extração de, na média e respectivamente, 33,$770 ; 58,420$ e $36,560 \mathrm{pg} / \mu \mathrm{l}$ de RNA. Esses resultados são significativamente melhores do que os verificados por Vincek et al.(16), que extraíram de 1,5 a 2,5 pg/ $\mu$ l de RNA a partir de material parafinizado. Entretanto, neste trabalho houve grande variação na quantidade do RNA extraído para cada caso, com valores oscilando entre 11,05 e $165 \mathrm{pg} / \mu \mathrm{l}$ no protocolo 2 , e entre 1,416 e $137,6 \mathrm{pg} / \mu \mathrm{l}$ no protocolo 3 (desvio padrão de 41,11 e 33,36 pg/ $/ \mathrm{l}$, respectivamente, para os procedimentos 2 e 3 ).

No que tange à relação custo-benefício, os três protocolos tiveram custos equivalentes. O kit RecoverAll Total Nucleic Acid Isolation Optimized for FFPE Samples, da Ambion, que foi a base do protocolo 1 , custa US $\$ 230$ e é suficiente para 40 amostras (US\$5,75 por amostra). O High Pure RNA Paraffin Kit, da Roche, que foi a base do protocolo 2 , custa US $\$ 512$ e é suficiente para cem amostras (US $\$ 5,12$ por amostra). O Absolutely RNA FFPE Kit, da Stratagene, que foi a base do protocolo 3, custa US $\$ 281$ e é suficiente para 50 amostras (US\$5,62 por amostra).
Neste estudo foi utilizado como primer o G6PD, o qual foi escolhido por ser um gene necessário à manutenção das funções celulares básicas e que, por essa razão, está constitutivamente presente em todas as células (do inglês housekeeping gene) $)^{(4)}$. Os dados do presente estudo indicam que, com o RNA extraído de amostras FFEP, é possível se realizar ensaios de RT-PCR utilizando-se primers cujo produto de amplificação tenha até 151 pares de bases de comprimento. Esses dados estão em concordância com os resultados verificados por Liu et al. ${ }^{(10)}$.

\section{Conclusão}

Com os três procedimentos utilizados, foi possível se extrair RNA de qualidade aceitável para RT-PCR $($ NIR $>1,4)$ em amostras de carcinomas mamários FFEP com 10 anos de arquivamento.

\section{Agradecimentos}

Todos os equipamentos e reagentes utilizados nesse trabalho foram gentilmente cedidos pela Dra. Stefanie Stein Jeffrey, da Universidade de Stanford, Califórnia, EUA.

\section{Referências}

1. BYERS, R. et al. PolyA PCR amplification of cDNA from RNA extracted from formalin-fixed paraffin-embedded tissue. Diagn Mol Pathol, v. 13, n. 3, p. 144-50, 2004.

2. CHUNG, J. Y.; BRAUNSCHWEIG, T.; HEWITT, S. M. Optimization of recovery of RNA from formalin-fixed, paraffin-embedded tissue. Diagn Mol Pathol, v. 15, n. 4, p. 229-36, 2006.

3. CRONIN, M. et al. Measurement of gene expression in archival paraffin-embedded tissues: development and performance of a 92-gene reverse transcriptasepolymerase chain reaction assay. Am J Pathol, v. 164, n. 1, p. 35-42, 2004.

4. EISENBERG, E.; LEVANON, E. Y. Human housekeeping genes are compact. Trends Genet, v. 19, n. 7, p. 3625, 2003.

5. FINKE, J. et al. An improved strategy and a useful housekeeping gene for RNA analysis from formalin-fixed, paraffin-embedded tissues by PCR. Biotechniques, v. 14, n. 3, p. 448-53, 1993.

6. GOLDSWORTHY, S. M. et al. Effects of fixation on RNA extraction and amplification from laser capture microdissected tissue. Mol Carcinog, v. 25, n. 2, p. 86-91, 1999.

7. HAMATANI, K. et al. Improved RT-PCR amplification for molecular analyses with long-term preserved formalin-fixed, paraffin-embedded tissue specimens. J Histochem Cytochem, v. 54, n. 7, p. 773-80, 2006.

8. KOOPMANS, M. et al. Optimization of extraction and PCR amplification of RNA extracts from paraffin-embedded tissue in different fixatives. J Virol Methods, v. 43, n. 2, p. 189-204, 1993.

9. KORBLER, T. et al. A simple method for RNA isolation from formalin-fixed and paraffin-embedded lymphatic tissues. Exp Mol Pathol, v. 74, n. 3, p. 336-40, 2003.

10. LIU, H. et al. Archival fixed histologic and cytologic specimens including stained and unstained materials are amenable to RT-PCR. Diagn Mol Pathol, v. 11, p. 222-7, 2002

11. MADABUSI, L. V.; LATHAM, G. J.; ANDRUSS, B. F. RNA extraction for arrays. Methods Enzymol, v. 411, p. 114,2006 
12. MASUDA, N. et al. Analysis of chemical modification of RNA from formalin-fixed samples and optimization of molecular biology applications for such samples. Nucleic Acids Res, v. 27, n. 22, p. 4436-43, 1999.

13. MUELLER, O. et al. A microfluidic system for highspeed reproducible DNA sizing and quantitation. Electrophoresis, v. 21, n. 1, p. 128-34, 2000.

14. RUPP, G. M.; LOCKER, J. Purification and analysis of RNA from paraffin-embedded tissues. Biotechniques, v. 6, n. 1 , p. 56-60, 1988

15. SCHROEDER, A. et al. The RIN: an RNA integrity number for assigning integrity values to RNA measurements. BMC Mol Biol, v. 7, p. 1-14, 2006.

16. VINCEK, V. et al. Methodology for preservation of high molecular-weight RNA in paraffin-embedded tissue: application for laser-capture microdissection. Diagn Mol Pathol, v. 14, n. 3, p. 127-33, 2005. 